\title{
La Australia argentina (1898): a utopia patagônica de Roberto \\ Payró.
}

\author{
José Bento de Oliveira Camassa*
}

\section{Resumo}

\begin{abstract}
La Australia argentina (1898), livro de viagem de Roberto Payró (18671928), escritor, intelectual socialista e repórter do importante jornal $L a$ Nación, de Buenos Aires, retrata a Patagônia mais de uma década depois da Conquista do Deserto (1879-1885). Em uma visão inspirada por um determinismo geográfico similar ao da obra "The Significance of the Frontier in American History" (1893) do historiador estadunidense Frederick Jackson Turner, Payró identifica na região um potencial civilizacional subaproveitado, em função da administração política demasiadamente centralizada e da herança colonial espanhola. O autor advoga pela modernização da Patagônia por meio de uma maior autonomia política e econômica e por meio da imigração europeia, especialmente a de colonos e pioneers anglo-saxões. Payró, aliás, revela um posicionamento fortemente anglófilo, em um período de afirmação da latinidade na intelectualidade hispano-americana, no contexto da Guerra Hispano-Americana (1898).

Palavras-chave: Roberto Payró; Patagônia; relato de viagem; Civilização; Pensamento Político latino-americano.
\end{abstract}

\section{La Australia argentina (1898): Roberto Payró's patagonian utopia}

\section{Abstract}

La Australia argentina (1898), travel book written by Roberto Payró (18671928), a writer, socialist intellectual and reporter for the important Buenos Aires's newspaper La Nación, portrays the Patagonia more than a decade after the Argentine Conquest of the Desert (1879-1885). Based on a Geographical determinism similar to Frederick Jackson Turner's "The Significance of the Frontier in American History" (1893), Payró identifies an under appropriated civilizational potential in Patagonia, because of the extremely centralized political administration and the Spanish colonial heritage. Payró advocates for Patagonia's modernization by the means of a greater political and economic autonomy for the region and the contribution of european immigration, especially anglo-saxon pioneers and settlers. Payró, moreover, shows a tight anglophile position, in a period marked by

\footnotetext{
Bacharel e licenciado em História pela Universidade de São Paulo. Mestrando em História Social pela mesma instituição, com bolsa FAPESP processo no 2018/02958-0 para o projeto de pesquisa "Itinerários da nação: identidade nacional e projetos de civilização nos escritos de viagem de Euclides da Cunha sobre a Amazônia brasileira e de Roberto Payró sobre a Patagônia argentina". A pesquisa busca comparar as representações feitas pelos autores sobre as regiões visitadas bem como suas propostas políticas, econômicas, técnicas e sociais em relação a elas. Contato: jose.camassa@usp.br. Agradeço os comentários e as sugestões feitas pelo(a) parecerista que avaliou este artigo para a Revista Leviathan. Elas serão incorporadas na elaboração da Dissertação de Mestrado.
} 
the vindication of the Latin Identity among Hispanic-American intellectuals, during the context of the Spanish-American War (1898).

Keywords: Roberto Payró; Patagonia; travel writing; Civilization; Latin American Political Thinking.

La Patagonia, ese ogro devorador para los que no la conocen, esa atrayente amiga para los hombres de empresa que la han visto una vez (Payró, 1898,

\section{Introdução}

Em 1898, o jornalista e escritor argentino Roberto Jorge Payró (1867-1928) escreveu, para o jornal bonaerense La Nación, uma série de crônicas - publicadas como folhetins - sobre a Patagônia. Os textos foram escritos a partir de viagem que fizera pelo litoral da região no mesmo ano, a bordo do Transporte Nacional Villarino. As crônicas patagônicas de Payró, ainda em 1898, em função de seu grande êxito comercial (Sarlo, 1984), foram reunidas sob a forma de livro, intitulado La Australia argentina e impresso pela gráfica do jornal.

Entre 1879 e 1885, a Argentina assistiu à Conquista do Deserto, uma série de ofensivas militares promovidas pelo Estado argentino - durante as presidências de Nicolás Avellaneda (1874-1880) e de Julio Argentino Roca (1880-1886) - no extremo sul americano. Mediante a captura, o extermínio, a dispersão e o desmantelamento das sociedades indígenas e gauchas locais, o Estado logrou conquistar as regiões dos Pampas ainda dominadas pelos indígenas, a Patagônia e a Terra do Fogo (Halperín Donghi, 2005; Passetti, 2012).

Duas décadas depois, a Patagônia, ainda superficialmente povoada, recobraria sua importância política em função do reaquecimento dos litígios fronteiriços entre Chile e Argentina pela região (Pompeu, 2012, p.136), a partir de 1896. É nesse contexto que Payró foi enviado pelo La Nación à Patagônia. Mesmo que suas crônicas não se concentrassem nesse conflito, a longínqua região voltara a ser pauta do dia.

Ainda que tenha caráter narrativo, o relato de Payró apresenta uma acentuada dimensão ensaística. Paul Groussac, importante intelectual franco-argentino finissecular, concebia a "viagem intelectual" - título de um texto de sua autoria, aliás como uma forma legítima e fértil de estudo (Colombi, 2004, p. 72), muito distante do 
mero turismo ${ }^{1}$. Nessa concepção, o viajante-escritor seria um agente na cena pública e sua viagem - por proporcionar o contato com realidades outras - seria um estímulo para a eleição e discussão de novos problemas intelectuais e políticos. Metaforicamente, a viagem abriria novos "percursos" de pensamento (Ibidem, p. 16).

Como mostra o estudo de Beatriz Colombi, a "viagem intelectual" gozou de grande prestígio entre os decênios de 1890 e 1910 e conferiu uma considerável autoridade discursiva à figura do intelectual-viajante entre os modernistas hispanoamericanos (Ibidem, pp. 13-17). Esse tipo de relato de viagem passou a ocupar um espaço de destaque na imprensa, como foi o caso de Payró. Em La Australia argentina, o autor, como intelectual, não apenas descreveu a realidade social patagônica, como também diagnosticou seus problemas e propôs soluções políticas para eles.

Neste trabalho, abordaremos um aspecto que atravessa o livro de Payró: o diálogo com a tradição intelectual argentina da geração de 1837 - principalmente, com Domingo Faustino Sarmiento (1811-1888) e Juan Bautista Alberdi (1810-1884) - e com o pensamento evolucionista do fim de século.

Essa interlocução permeia os posicionamentos que o autor adota em relação aos seguintes temas: as políticas do governo central argentino para a Patagônia; a herança colonial hispânica; e a imigração europeia como proposta política para o desenvolvimento econômico e a forja de uma nova identidade étnica na região.

\section{Civilização e barbárie nas obras de Payró: a denúncia dos vícios}

\section{da política criolla}

A tópica sarmientina da contraposição entre civilização e barbárie está presente não apenas em La Australia argentina, como também em boa parte da produção jornalística e ficcional de Payró. Sobretudo, no que concerne a uma retórica

\footnotetext{
${ }^{1}$ Com o surgimento de uma indústria turística na Belle Époque, boa parte da intelectualidade hispanoamericana procurou distinguir seus escritos de viagem dos meros guias de viagem que se disseminavam à época. O modernista Rubén Darío, por exemplo, frequentemente registra certo desdém não só em relação aos manuais de viagem bem como à própria figura do turista (Montaldo, op. cit., p. 22). Essa era entendida como desprovida de reflexão intelectual sobre seus itinerários e como passiva diante de circuitos culturais artificialmente fabricados (Colombi, 2004, pp. 200-212; Pera, 1998, p. 512).
} 
anti-criolla, isto é, crítica à política tradicional criolla: seus líderes, valores e instituições ${ }^{2}$.

Anos antes de ser enviado à Patagônia, o autor já fizera reportagens no litoral, no interior da província de Buenos Aires e de outras províncias argentinas sobre disputas políticas locais (Pastormelo, 2009). Nessas matérias, tecia incisivas reprimendas a

la corrupción, el fraude político y el caciquismo a los que se verían sometidas la población inmigrante y criolla de la campaña. Esta mirada crítica al "atraso político" de las zonas rurales del país ha sido puesta en vinculación con la militancia socialista de Payró de aquellos años. Según Beatriz Sarlo, la "fenomenología de la política criolla" que presentaba en sus crónicas se inscribía en el registro proporcionado por las propuestas de transformación y modernización de la cultura política que el socialismo argentino y, sobre todo, Juan B. Justo, buscaban liderar (...) (Buonuome, 2017, p. 169).

A preocupação com tais temas estava em sintonia com os posicionamentos políticos de Payró. Na década de 1890 , o jornalista conciliava sua adesão ao Partido Socialista argentino e ao Centro Socialista Obrero com um firme apoio à Unión Cívica ${ }^{3}$. Na direção do La Tribuna, de Bahia Blanca, apoiou a Revolução do Parque (1890), assumindo um ferrenho antirroquismo (Pastormelo, 2009). Nessa posição, Payró nutria grande admiração por Leandro Alem (1842-1896), representante da ala mais radical da Unión Cívica, e se aproximou de Bartolomé Mitre (1821-1906), líder da ala mais moderada do grupo. Essa aproximação, aliás, foi um dos fatores que possibilitou o

\footnotetext{
2 'Como sucede con el término 'criollo', que en el uso de las elites intelectuales de la segunda mitad del siglo XIX se había cargado de connotaciones negativas condensadas en torno a dos ejes: el del trabajo y el del progreso.” (Altamirano; Sarlo, 1997, p. 183).

${ }^{3}$ Tais filiações políticas não eram incongruentes, uma vez que na década de 1890, o Partido Socialista argentino ainda não se distanciava tanto do ideário político e econômico liberal - característico do Mitrismo. Um dos principais dirigentes e fundadores do Partido, Juan B. Justo, combinava "su marxismo positivista, la filosofía kantiana e un fervoroso livre cambismo económico" (Parson, 2001, p. 64). Numa linha reformista, o Partido Socialista argentino apresentava "como características históricas particulares, a de ser um partido pré-bolchevique somando-se rapidamente a II Internacional, a Internacional Socialista, que existiu entre 1889 e 1918, e de tomar precocemente, embora não em seu congresso institucional, as bandeiras do reformismo. Procurando aprender da experiência histórica dos partidos socialistas europeus, considera fundamental incorporar os elementos mais modernos do socialismo de sua época histórica: os elementos organizativos da social democracia alemã, o modelo do trabalho cooperativista do socialismo belga e as ideias do teórico e político socialista pacifista francês Jean Jaurés. Este é o reformismo que influência de maneira mais forte o PS, mas que o próprio Edouard Berstein, com o qual coincidem certamente muito mais em política que em teoria" (Rojas, 2013, p. 71).
} 
ingresso de Payró no La Nación, jornal de propriedade da família desse ex-presidente argentino ${ }^{4}$.

Por seu arcaísmo e corrupção, a política criolla era identificada por Payró sob o signo da "barbárie". Essa associação (Sarlo, 1984, p. xviii, p. xxviii) foi o leitmotiv de Divertidas Aventuras del Nieto de Juan Moreira (Payró, 2012), de 1910. Esse romance ironiza Mauricio Gómez Herrera, personagem alegórica da elite criolla, que se autointitula herdeiro do lendário gaucho Juan Moreira. Na obra, Herrera, filho de um mandatário da fictícia cidade provinciana de Los Sunchos, é satirizado como emblema da desfaçatez, despreparo e arbitrariedade das elites rurais argentinas. A caracterização do protagonista, desde a tenra idade, como atavicamente indisciplinado, voluntarioso e refratário ao ideário burguês de valorização do trabalho ${ }^{5}$, o aproxima da figura do caudilho, símbolo máximo do despotismo, de acordo com o Facundo (1845), de Domingo Faustino Sarmiento $(1997)^{6}$.

Em La Australia argentina, contudo, Payró vislumbra uma possibilidade de superação dessas arraigadas mazelas políticas na recém-incorporada Patagônia. Logo

\footnotetext{
${ }^{4}$ A despeito de sua ligação com o Mitrismo, deve-se pontuar certa independência e divergência de Payró em relação a essa corrente política. Para o autor, "Mitre era menos una voz doctrinaria que una figura ejemplar. (...) Cuando Mitre pactó con Roca en 1891 (...) [Payró] consternado, escribió entonces que Mitre ya no era Mitre ('¡Mitre no es ya!'), como si preservara una figura ideal, previa y subsistente, de equivocaciones o traiciones incapaces de alterarla" (Pastormelo, 2009).

${ }^{5}$ Nesse sentido, é possível traçar um paralelo desse romance com Memórias Póstumas de Brás Cubas (1881), de Machado de Assis, na medida em que tanto Herrera quanto Cubas apresentam pouca disposição para o trabalho, para o estudo e para a disciplina. Como o crítico literário Roberto Schwarz aponta, a personagem de Brás Cubas pode ser vista como um símbolo das elites proprietárias brasileiras oitocentistas, seus privilégios econômicos e sociais e sua adesão superficial e meramente formal a valores burgueses. Nas palavras de Schwarz, na obra de Machado de Assis, "embora muito solta, a forma do romance é biográfica (...). Passam diante de nós as estações da vida de um brasileiro rico e desocupado: nascimento, o ambiente da primeira infância, estudos de Direito em Coimbra, amores de diferentes tipos, veleidades literárias, políticas, filosóficas, científicas, e por fim a morte. Estão ausentes do percurso o trabalho e qualquer forma de projeto consistente. A passagem de uma estação a outra se faz pelo fastio, imprimindo ao movimento a marca do privilégio de classe. (...) A volubilidade de Brás aparece, como o reverso da exclusão de trabalho ou empenho autêntico, e como extensão da iniquidade social.

Subordinado ao capricho, o elenco das finalidades-mestras da vida burguesa toma feição barateada, com alguma coisa de opereta. Assim, no lugar do Estudo temos alguns anos de Folia em Portugal; (...) no da Política, um discurso parlamentar sobre a conveniência de diminuir em duas polegadas as barretinas da Guarda Nacional, de modo a torná-las mais leves e maneiras. A Filosofia é representada por reflexões sociais inspiradas em brigas de cachorro, ao passo que a invenção do Emplastro Brás Cubas faz as vezes de Ciência e Livre Empresa" (Schwarz, 2012, pp. 63-64). Tanto Herrera como Cubas, portanto, são apresentados como medíocres em suas trajetórias acadêmicas e políticas.

6 "En el caso de $D A$, como el obstáculo para la civilización de las costumbres políticas y para praticar la escisión del manejo de la tierra y el catastro respecto del poder político, según un diagnóstico clásico de Sarmiento en Facundo, acerca de la fuente de donde emanaba el poder político basado sobre la propriedad rural corrompe el espíritu público y hace imposible el surgimiento de lo público como forma moderna de la política y del gobierno" (Sarlo, 1984, p. XXVIII)
} 
no primeiro folhetim, declara que tinha o antigo desejo de "conocer esas tierras patagónicas en que muchos hombres de pensamiento cifran tan altas esperanzas" (Payró, 1984, p. 313) como por poder ser útil aos "habitantes cuasi solitarios de aquellas apartadas comarcas" (Ibidem, idem). Ao longo das crônicas, o literato corrobora sua impressão inicial e discerne um grande potencial econômico e civilizacional na região.

Como aponta o crítico Jens Andermann (2000, p. 73-75), a representação que Payró esboça da Patagônia não apenas procurou desvincular a região do antigo rótulo de "terra maldita" e completamente estéril, consagrado pelo relato de Darwin a partir da viagem do Beagle (Torre, 2007), de 1833. Pelo contrário, com grande otimismo, o autor considerava que a área poderia futuramente constituir o esteio de uma "refundação" da República Argentina (Andermann, op. cit., p. 76) em bases políticas e econômicas modernas. Ou seja, para o jornalista, a Patagônia não apenas poderia se tornar imune da viciosa política criolla como também ela ofereceria a receita para superá-la.

Em linhas gerais, o projeto político "civilizador" que Payró defende para a Patagônia está calcado em dois pilares. O primeiro consiste na integração da região com as demais partes da Argentina, superando seu isolamento e, por conseguinte, seu caráter ainda "desértico" e "bárbaro". O segundo concerne ao povoamento da região por meio da imigração europeia - particularmente, a anglo-saxã. Para o autor, esse afluxo migratório não teria fins estritamente demográficos. Seria uma estratégia de fomento ao desenvolvimento material e de formação de uma nova identidade étnica e cultural, supostamente mais propícia para uma modernização política e econômica.

\section{O isolamento e o "atraso" da Patagônia no Pós-Conquista do}

\section{Deserto}

La Australia argentina pode ser considerado como um manifesto em defesa das plenas possibilidades civilizatórias na Patagônia. Ainda que reconheça as intempéries climáticas, o autor procura desmistificá-las e mostrar que o perfil geográfico 
patagônico não seria de fato incompatível com o desenvolvimento agrícola ${ }^{7}$, urbano, demográfico e econômico ${ }^{8}$. Assim, apresentando detalhadas estatísticas metereológicas, aponta as proximidades de perfil climático entre a Terra do Fogo e Dublin (Payró, 1898, p. 311). No mesmo sentido, Payró comenta que, apesar do frio intenso, não teve nenhum resfriado em sua viagem (Ibidem, p. 418). Ou seja, o relato de viagem de Payró procura matizar a identificação da Patagônia como desierto absolutamente hostil à civilização.

Porém, deve-se ponderar que a obra não se exime de discutir os empecilhos para o estabelecimento da "civilização" na Patagônia, bem como de apontar os signos sociais da "barbárie" na região. Ao fazê-lo, entretanto, não os atribui a uma natureza inata dos confins austrais, mas a questões políticas e sociais da Argentina como um todo.

Por vezes, as crônicas de Payró reverberam a imagem, forjada por relatos de viagem de argentinos e estrangeiros, da Patagônia como lugar de desesperado embate entre o ser humano e a natureza inóspita (Torre, 2007). No livro, essa visão é sugerida a partir de relatos, coletados junto aos habitantes locais, que abordam a luta pela sobrevivência por parte de aventureiros - principalmente mineiros, lobeiros e caçadores de foca - que se lançaram à Patagônia. Há histórias de naufrágios, enfrentamentos e assassinatos de indígenas bem como de situações-limite - por exemplo, a hidratação por meio da ingestão de sangue de cavalo, nos períodos de falta d'água em Chubut (Payró, 1898, pp. 34-35) e o consumo de carne humana na Terra do Fogo ${ }^{9}$.

\footnotetext{
7 “Al contrario de la creencia general á propósito de la Patagonia, los campos son buenos aunque sin agua hacia la costa" (Payró, 1898, p. 47).

${ }^{8}$ Ainda que aborde frequentemente as dificuldades da rotina marítima, Payró não pretende assumir um tom épico ou aventuresco, recorrente nos relatos de exploração patagônicos das décadas e séculos anteriores (Torre, 2007; Andermann, 2000). Realizando sua viagem já nos marcos da modernidade técnica, afirma: "No se espere hallar aquí el relato de múltiples y peligrosas peripécias: no las hubo. Apenas las incomodidades que nunca faltan en una excursión cualquiera, y nada más" (Payró, 1898, p. 419; grifo nosso).

${ }^{9}$ Considerando que Payró escrevia para o público-leitor metropolitano de Buenos Aires, não se pode ignorar a hipótese de o jornalista carregar nas tintas, a fim de reforçar a dimensão de alteridade - central em qualquer relato de viagem (Hartog, 1999) - que a Patagônia representava e despertar maior interesse de seus leitores. La Australia Argentina foi um grande sucesso editorial, em função do desconhecimento e da curiosidade dos portenhos em relação à Patagônia. A comparação entre a capital e a região é mencionada em outros momentos do livro. Por exemplo, quando Payró comenta que o mate - que lhe fora um grande "ajudante" na viagem - tinha um "império" em toda a Argentina, exceto em Buenos Aires que, mais europeizada, recusava o tradicional consumo da erva (Payró, 1898, p. 256). Sobre a desvalorização
} 
Contudo, tais episódios são associados à figura específica do aventureiro patagônico. Payró analisa sociologicamente a emergência desse tipo social como um produto das condições de vida precárias das populações pobres nos grandes centros urbanos (Ibidem, pp. 309-310), o que teria levado muitos indivíduos a tentar a sorte no sul argentino. Ainda que considere eticamente condenáveis as condutas desses aventureiros, o jornalista as relativiza, afirmando que os limites de consciência são forçosamente mais maleáveis em contextos de grande penúria e adversidade. Em acréscimo, Payró não julga esses comportamentos como fruto da paisagem patagônica, mas dos problemas sociais urbanos e desequilíbrios geográficos entre as províncias e a capital na Argentina. Crê, inclusive, que a Patagônia pode, plenamente, oferecer recursos para a ascensão social e "moralização" dos aventureiros, desde que o governo central adote medidas políticas mais favoráveis para o desenvolvimento da região.

Essa postura do autor se distancia, sugestivamente, da clássica tópica das planícies e dos desiertos como produtores atávicos da "barbárie" na sociedade, na cultura e na política da Argentina. Alguns trechos de Facundo bem o expressam:

\footnotetext{
Muitos filósofos acreditaram (...) que as planícies preparavam o caminho ao despotismo, do mesmo modo que as montanhas permitiam as resistências da liberdade.

(...) Esta extensão das planícies imprime (...) à vida do interior certa tintura asiática que não deixa de ser pronunciada.

(...) O capataz é um caudilho, como na Ásia o chefe de caravana. (...) É assim que na vida argentina começa a estabelecer-se (...) o predomínio da força bruta, a preponderância do mais forte, a autoridade sem limites e sem responsabilidades dos que mandam, a justiça administrada (...) sem debate (Sarmiento, 1999, pp. 69-71).
}

Logo, de certa forma, a análise de Payró sobre a Patagônia se distancia da matriz interpretativa sarmientina, nesse aspecto. Mesmo que tanto Sarmiento como Payró almejassem o adensamento demográfico das planícies argentinas, o segundo autor relativiza a dimensão - supostamente inerente - de desierto da Patagônia e o alegado caráter socialmente deletério desse ambiente. Pelo contrário, chama o extremo sul argentino de "zona tão favorecida pela natureza" (Payró, 1898, p. 111). Ainda em diferença em relação a Sarmiento - pelo menos, aquele de Facundo -, o 
jornalista matiza a associação de pares civilização e cidade vs. barbárie e campo, uma vez que identifica potenciais civilizatórios próprios do espaço rural do extremo sul argentino.

Para Payró, os arcaísmos políticos, econômicos e sociais da Patagônia decorreriam de seu isolamento em relação às áreas mais centrais da Argentina e não de suas características regionais intrínsecas. Isolamento, esse, mantido por decisões políticas de Buenos Aires. "Patagonia, más que geográficamente, está alejada del resto de la república por la indiferencia" (Payró, 1984, p. 346), afirma o repórter. Em outra passagem, utilizando uma metáfora de parentesco, qualifica a região como "enteada":

Patagonia es hijastra. Tiene toda la voluntad de las hijastras, descuidadas y sin embargo dignas de atención, de respeto, de ayuda. Si sus cualidades naturales responden á su ambición, puede que triunfe sobre sus hermanas (Payró, 1898, p. 111; grifos nossos).

Escrevendo em um contexto posterior à Conquista do Deserto, Payró diagnostica que a Patagônia, embora já incorporada de direito ao Estado argentino, não o está de fato. Assim, o principal alvo do jornalista é o governo central argentino ${ }^{10}$, por mais que critique o autoritarismo e a incompetência de algumas autoridades locais (Payró, 1898, p. 349) - afinal, a quase totalidade delas havia sido nomeada diretamente por Buenos Aires ${ }^{11}$. A título de exemplo, é ao governo central que Payró responsabiliza pelo fato de o Estado de direito não imperar na Terra do Fogo (Ibidem, pp. 285-286, p. 309), na medida em que a proibição da mineração de aluvião e da caça de anfíbios não teria sido efetivamente implantada e nem traria benefícios para o país ou para os colonos locais: "Lo único que se logra com ella [a proibição] es que la República, burlada, no alcance ningún beneficio de sus riquezas (...)” (Ibidem, p. 286; grifo nosso).

\footnotetext{
${ }^{10}$ No início de 1898, período de escrita de La Australia argentina, a Presidência - após um breve interregno radical - estava novamente nas mãos de um partidário de Julio Argentino Roca, José Evaristo Uriburu. Como Payró e Mitre eram adversários - mais ferrenho, o primeiro e mais moderado, o segundo - do Roquismo, não surpreende que o livro critique as ações do governo central à época.

11 A administração da Patagônia era extremamente centralizada. Magistrados, burocratas e chefes executivos das Gobernaciones do Território Nacional da Patagônia (Neuquén, Chubut, Santa Cruz e Terra do Fogo) eram nomeados diretamente pelo Executivo central, com aval do Senado, conforme a lei 1532 de 1884. As Gobernaciones eram politicamente dependentes do governo federal e, diferentemente das províncias, não tinham direito à representação no Congresso Nacional (Pompeu, 2012, pp. 137-140).
} 
Pode-se fazer a ressalva de que Payró não nega as imensas solidões geográficas do extremo austral argentino. Entretanto, considera a região refém do abandono do governo central ${ }^{12}$. Esse desamparo, mais do que as características ambientais inóspitas, é que manteria - ou intensificaria - o aspecto de desierto da Patagônia ${ }^{13}$.

A crítica mais incisiva e reiterada ao longo da obra é em relação à precariedade dos meios de transporte - quase que exclusivamente marítimos - que atendiam a Costa Sul argentina, uma reclamação registrada entre habitantes de todas as cidades visitadas por Payró (Ibidem, p. 51). De acordo com eles, as linhas de navios entre Buenos Aires e a Patagônia eram parcas, tinham intervalos longos, não passavam por todos os principais portos da região e ofereciam poucas condições de segurança e higiene - acarretando risco de perda de produtos, como no caso de um comerciante inglês que desiste de embarcar sua lã para a capital porque no navio ela ficaria extremamente suja (Payró, 1898, p. 11). Assim, a fragilidade das vias de integração territorial seria um fator determinante para a Patagônia não aproveitar seus potenciais econômicos.

Diante do grande desenvolvimento tecnológico da Belle Époque, o problema não seria mais a distância geográfica da região, mas a falta de uma rede náutica estruturada para conectá-la a Buenos Aires: “iY dicen que esta línea de transportes [Transporte Nacional Villarino] que hace un viaje al mes, tiene por objeto el desarollo de aquellas regiones!" (Ibidem, p. 9) ${ }^{14}$. Tal insuficiência estimulava, inclusive, a existência de troca de favores entre comerciantes locais e capitães de navios. Esse exemplo é significativo na medida em que Payró coloca a corrupção como consequência das condições políticas impostas pelo governo central e não das características da Patagônia em si.

\footnotetext{
${ }^{12}$ O Governador da Terra do Fogo conta a Payró: "Cuando vuelva á Buenos Aires, vaya al ministério del Interior y al de Hacienda, y verá mis rimeros de notas, inútiles, completamente inútiles, porque no les han hecho caso, aunque tratara de asuntos de vital importância para el territorio" (Payró, 1898, p. 285).

${ }^{13} \mathrm{O}$ peso da falta de infraestrutura para o isolamento do extremo austral argentino pode ser verificado em um comentário curioso de Payró acerca da Isla de los Estados: "Allí se dice generalmente, cuando hace um dia hermoso: - Hoy llega transporte. O viceversa, cuando el transporte há fondeado en la mañana: Hoy tendremos sol. Será porque el jubile producido por el único acontecimiento feliz, hace parecer hermosos los días que en otras circunstancias no llamarían la atención?” (Payró, 1898, p. 342)

${ }^{14}$ Nesse sentido, o autor propõe a criação de linhas de vapores particulares - mas subvencionadas pelo Estado - que interligassem a Patagônia e Buenos Aires (Payró, 1898, pp. 10-11).
} 
Outro fator que minava o crescimento econômico e populacional da Costa Sul argentina, na interpretação do escritor, era o fato de seus portos não serem livres. Isso dificultava a aproximação da região com Buenos Aires e também com a Europa. Nessa chave, Payró compara o incipiente desenvolvimento das cidades litorâneas da Patagônia argentina com a suposta pujança da chilena Punta Arenas, porto livre no Estreito de Magalhães.

Na breve passagem pela cidade, o autor a qualifica como "joia" e comenta, embasbacado, que havia retornado instantaneamente ao "mundo civilizado". Nesse porto chileno, os meios de comunicação e transporte eram abundantes e eficientes. Havia várias linhas de vapores quinzenais, transatlânticos - permitindo a ligação com Santiago do Chile, com a Patagônia argentina e mesmo com a Europa e a Califórnia, o que dava um ar cosmopolita à cidade -, embarcações de cabotagem com fins comerciais específicos e vapores-correios subvencionados pelo governo chileno ${ }^{15}$. A força comercial dava ao município considerável prosperidade - Payró até se surpreende com alguns palacetes da elite local (Payró, 1898, p. 447) ${ }^{16}$-, além de certa vitalidade urbana: ruas movimentadas e "risonhas", bares e clubes, além da promessa da instalação de iluminação pública e de linhas de telégrafo nos anos seguintes (Ibidem, pp. 134-144).

Segundo Payró, a atuação do Estado havia sido fundamental para o êxito de Punta Arenas. Desde que o comércio despontara, em razão da localização estratégica da cidade, o governo chileno imprimiu uma série de medidas para potencializar seu crescimento econômico: investiu em obras públicas, fomentou o povoamento da cidade e concedeu a franquia a seu porto ${ }^{17}$. Além disso, teria se adotado uma legislação de grande liberalidade, o que, segundo Payró, contrastaria com a política argentina para a Patagônia: "todo es exigencia de parte de los argentinos para aquellos

15 Mesmo em cidades importantes da Patagônia argentina, como Gallegos, os habitantes seriam dependentes do comércio com Punta Arenas, pela dificuldade de ligação com outras cidades argentinas. Dessa forma, eles seriam obrigados a ser "semi-chilenos" (Payró, 1898, p. 111; cf. p. 31, p. 322).

${ }^{16}$ Em 1895, por exemplo, foi construído o Palacio Sara Braun, pertencente a uma rica família de Punta Arenas (Inostroza Pino, 2008, p. 17).

${ }^{17}$ Vale destacar que o status de porto livre de Punta Arenas não pode ser considerado exclusivamente no âmbito do Estado nacional chileno. Em razão de sua localização estratégica, entre o Atlântico e o Pacífico, diversas nações europeias tinham grande interesse pela navegação através do Estreito de Magalhães (Passetti, 2014). O fato de o Chile não ter força militar e diplomática para se opor a essa navegação ou lhe impor fortes restrições alfandegárias contribuiu para que Punta Arenas se tornasse um porto livre, o que permitia o acesso das potências marítimas. 
parajes; todo es tolerancia, de parte de los chilenos, para aquella comarca" (Ibidem, p. 111).

De acordo com Payró, a proibição de portos livres na Patagônia - com exceção dos de Gallegos e Santa Cruz, por um curto intervalo de tempo (Ibidem, pp. 22-29) estaria a serviço das províncias argentinas, ao norte do Rio Negro, com perfil econômico agrícola. $\mathrm{O}$ autor, primeiramente, procura desconstruir a velha tese de que seria necessária uma política protecionista para o comércio patagônico, argumentando que, em função de sua debilidade, tratava-se de preocupação extemporânea (Payró, 1984, p. 350). Em seguida, endossa a opinião corrente na Patagônia de que as províncias agrícolas argentinas, dotadas de uma tradicional influência e representação política, temiam que, se fossem declarados livres os portos da Costa Sul, os agricultores que perdessem suas colheitas migrariam em massa para a região (Ibidem, idem).

Outro exemplo da pouca autonomia que Buenos Aires concedia ao extremo sul se via na dificuldade do acesso à terra, só aparentemente barata, na Terra do Fogo:

(...) los compradores no pueden hacer la operación en Tierra del Fuego, sino que tienen que venir á Buenos Aires á tramitarla en el ministerio, ó nombrar un apoderado que se encargue de ella, con los gastos y tropiezos consiguientes... (Payró, 1898, p. 286)

Dessa forma, aponta o autor, um lote havia sido adquirido em Ushuaia pela última vez apenas em 1895, três anos antes da escrita do livro (Ibidem, idem). Na Patagônia como um todo, o cenário era marcado por uma grande concentração e especulação fundiária (Pompeu, 2012, pp. 140-141). Payró não se furta a analisar como essa característica afetava a vida política desse espaço geográfico:

\footnotetext{
La tierra (...) está en poder de compañías especuladoras y avaras (...). La seguridad de nuestras campañas ha sido y es un mito, pues las autoridades encargadas de velar por ella, se nombran con miras inconfesables de dominio político y con el mismo fin se les dejan facultades tiránicas de que todavía abusan. La justicia es (...) tarda, tortuosa, cara, terrible para quien acude á ella, por más que tenga razón (Payró, 1898, pp. 444-445; itálico do autor, grifos nossos).
}

Sobressai nesse trecho a proximidade com o vocabulário e o diagnóstico político de Facundo. Payró de fato identifica na Patagônia muitos traços da arbitrariedade e do "atraso" criollos, temas longamente abordados no clássico de 1845 
de Sarmiento. Porém, à diferença de Sarmiento, Payró diagnostica a origem de tais males não nas áreas interioranas em si, mas nas condições políticas e sociais que lhe foram impostas pelo Estado nacional.

\section{4 - $O$ preterimento da Patagônia e a herança colonial espanhola.}

Mas Buenos Aires não é o único alvo de Payró. O jornalista remonta à colonização espanhola para demonstrar como eram arraigados o abandono e a insensatez política na administração dos territórios patagônicos. 0 autor recorda o caso do explorador Francisco Viedma, que, a mando da Coroa espanhola, em 1782 fez uma expedição de reconhecimento da Patagônia. Embora tenha escolhido o porto de San Julián como o melhor lugar em toda a Patagônia para um estabelecimento comercial, o Vice-rei do Rio da Prata ordenou o abandono desse porto (Payró, 1898, p. 112). Viedma protestou, sem sucesso, em razão das vantagens oferecidas por esse local e pelos gastos que se já haviam feito nele. Mais de um século depois, Payró constata:

\footnotetext{
Ese sistema de población y abandono lo ha continuado y perfeccionado en la República Argentina (...) gastando sumas importantes sin beneficio para nadie, ó mejor dicho, con particular beneficio para unos pocos (...). Pero es tiempo de que esto cese, tanto más, cuanto que la experiencia ha costado millones al país, y nuestros vecinos han llegado á éxito mayor con menor esfuerzo, sencillamente porque han sabido administrar (...) (Payró, 1898, pp. 111-112; grifos nossos).
}

Na mesma chave, o autor sentencia que "la Argentina ha heredado de España su falta de aptitudes de colonizadora, que constituirá un peligro si se continúa en el mismo rumbo" (Payró, 1898, p. 287). Payró também compara o desinteresse argentino pela Patagônia com a política estratégica adotada pelo Estado inglês em relação ao extremo austral americano, quando este, antes de formalmente incorporado pelo país latino, era considerado res nullius: "Inglaterra envio á éstos [territórios] sus exploradores y avanzadas en forma de misioneros, conociendo el mérito de esas tierras" (Ibidem, idem).

A menção elogiosa à Inglaterra, justaposta à reprovação da colonização espanhola, traz à tona um dos pontos centrais da obra de Payró: a defesa do modelo 
econômico, social e administrativo das regiões "semi-virgens" do mundo anglo-saxão, como o Oeste dos Estados Unidos da América, a África do Sul e a Austrália. O título La Australia argentina, dessa forma, não se refere apenas à localização austral da Patagônia, como também expressa uma forte simpatia de Payró em relação aos anglosaxões, vistos como supostos modelos de modernidade e desenvolvimento econômico ${ }^{18}$.

Essa visão estava relacionada ao contexto da Guerra Hispano-Americana, que se desenrolou entre maio e agosto de $1898^{19}$. Esse período coincidiu com o fim da viagem de Payró - seu retorno a Buenos Aires se dá em maio do mesmo ano - e os meses de publicação dos folhetins de La Australia argentina no La Nación - de maio a setembro de 1898. Ainda que haja apenas uma tímida referência direta à Guerra Hispano-Americana em toda a obra ${ }^{20}$, as teses de La Australia argentina estão intimamente ligadas à percepção de decadência espanhola, ratificada pela Guerra.

À diferença de colegas modernistas, como Rubén Darío (1998) e Paul Groussac (1898), Payró não aderiu à celebração do passado espanhol, nem à defesa da aproximação identitária dos países hispano-americanos ${ }^{21}$ em torno dos costumes e da tradição cultural latina em comum (Capelato, 2003) ${ }^{22}$. Payró preocupou-se justamente

\footnotetext{
${ }^{18} \mathrm{O}$ desenvolvimento do Sul argentino já era tema caro a Payró desde sua passagem por Bahia Blanca, cidade no sul da província de Buenos Aires e próxima ao Rio Negro, marco do norte da Patagônia. Em 1891, o autor já chama a cidade de "Australia del Sud" e aspira a seu desenvolvimento econômico: "En efecto, mucha gente de equívocas costumbres, así como algunos criminales (... ) formaron este centro que hoy es el tercer mercado de lanas de la América Meridional, y que está llamado a ser en breve el primero, si es que las probabilidades infinitas que se tienen no fallan" ("Un poco de historia - Bahía Blanca", La Tribuna, Bahía Blanca, 24 de septiembre de 1891, apud Pastormelo, 2009, p. 39).

${ }^{19}$ Vale ressaltar, no entanto, que desde as Independências, intelectuais hispano-americanos que viajaram aos Estados Unidos já projetavam diferenças identitárias entre anglo-saxões e latinos, sendo recorrente a associação dos primeiros a um espírito sóbrio e pragmático (Franco, 2017). A querela entre anglicismo e latinismo, em meados do século, também reverberou a Guerra Mexicano-Americana (1846-1848).

${ }^{20}$ Essa menção é a reprodução da notícia "La guerra hispano-americana continúa. Ha habido un combate en..." (Payró, 1898, p. 442), entre os jornais que os viajantes recém-chegados da Patagônia recebiam.

${ }^{21}$ Payró provavelmente ainda não havia retornado a Buenos Aires em 2 de maio de 1898 , dia em que se realizou no Teatro de la Victoria o ato organizado pelo Club Español, a propósito do cenário geopolítico envolvendo a Guerra Hispano-Americana e suas consequências. O ato teve como oradores José Tarnassi jurista e imigrante italiano - Roque Sáenz Peña, advogado e representante da Argentina na Primeira Conferência Panamericana (Washington, 1889-1890) e Paul Groussac - destacado intelectual francoargentino do fim de século. O discurso de Sáenz Peña expôs um rechaço ao panamericanismo e ao expansionismo estadunidense e o de Groussac valorizou a herança cultural latina dos países hispanoamericanos, que se contraporia ao suposto materialismo e anti-intelectualismo dos Estados Unidos.

${ }^{22}$ Em meados do século XIX, a identificação de uma América "Latina", em contraposição à anglo-saxã, já havia sido sugerida por autores como Torres Caicedo e Michel Chevalier (Mignolo, 2012).
} 
com a criação de um futuro modernizador para a Patagônia e, em certa medida, também para a Argentina. Para tanto, a senda que indicava era claramente anglófila.

\section{A Patagônia como Far South argentino}

Como já abordado, Payró procurou não apenas relativizar o caráter de desierto da Patagônia, bem como apresentar os trunfos sociais e econômicos que esse espaço geográfico poderia oferecer. $\mathrm{O}$ autor considerava a Patagônia destinada a ter um futuro extremamente próspero, especialmente se aberta à instalação de imigrantes europeus.

Essa avaliação decorria da percepção determinista dos territórios de fronteira como áreas supostamente privilegiadas para o desenvolvimento material e aprimoramento moral ${ }^{23}$. Trata-se de tópica intimamente associada ao exemplo do Oeste estadunidense, consagrado pelo historiador Frederick Jackson Turner (18611932) em conferência de 1893 (2004). De acordo com Turner, o processo de expansão rumo ao Oeste teria cunhado as instituições e o "caráter" nacional estadunidense (Torre, 2007, p. 229). Em meio ao alargamento da fronteira, o desbravamento do "wilderness - a natureza inóspita e remota" (Turner, 2004, p. 25) teria fomentado "a demanda por terra e o amor à liberdade" (Ibidem, p. 41) nos Estados Unidos.

O repórter do La Nación indica claramente o modelo do Oeste desse país ao declarar que

Pretendemos servirnos de la experiencia de Estados Unidos, y no acertamos a imitarlos en aquello que ha cooperado con más eficacia a su engrandecimiento, como las extraordinarias facilidades que dieron para poblar sus comarcas desiertas y la absoluta libertad que gozaron sus habitantes. Aquí [na Patagônia argentina] todas son trabas, y cuando el Pioneer se lanza por fin a aquellos incultos y pobres campos, después de vencer dificultades sin cuento, encuentra en las autoridades el mismo afán de gobierno a todo trance que viviendo en un centro de civilización (Payró, 1984 p. 351).

\footnotetext{
${ }^{23}$ Payró e boa parte dos socialistas platinos da época, como Juan B. Justo e Alfredo Palácios, estavam afinados com o pensamento evolucionista, particularmente com as obras do antropólogo estadunidense Lewis Morgan (Barrera, 2011). A visão evolucionista era articulada com as propostas gradualistas e reformistas que esse grupo socialista advogava, já que esses intelectuais consideravam a sociedade industrial e moderna como um estágio superior de civilização, que deveria ser alcançado pela Argentina.
} 
Dessa forma, para Payró, o papel do Estado argentino na Patagônia deveria ser o de fornecer a infraestrutura básica - efetivos sistemas de transportes e faróis marinhos, implantação de poços e cisternas para suprimento de água, instalação de ferrovias e linhas de telégrafo ${ }^{24}$ etc. -, garantir a facilidade da compra de terras e franquear as mais amplas liberdades civis e comerciais - o que incluía a liberação de quaisquer tarifas alfandegárias nos portos. Assim, o apartamento dos territórios patagônicos em relação a Buenos Aires poderia ser extremamente positivo, desde que tais áreas contassem com apoio estatal mínimo e com autonomia política máxima. Tal é a confiança do jornalista nesse modelo político que chega a ter rompantes de sonho sobre o porvir patagônico:

\begin{abstract}
Patagonia estaba ya poblada desde Viedma hasta la punta Dungeness, desde el Atlántico hasta los valles habitables de los Andes; (...) luego la población se hacía más densa a medida que avanzaba la falda de la cordillera, donde vivía con una vida intensa y pacífica, libre y feliz. (...) Los trenes llevaban a la costa los productos de todo el interior. (...) perdía Patagonia su fisonomía misteriosa y amenazadora, y de aquel territorio inculto y casi desierto, surgían una, dos, tres provincias que reclamaban el self-government, con más razón que muchas otras, diciendo: “iAh! Nos habéis dejado, y hemos crecido solas, por nosotras mismas, con nuestras fuerzas personales, sin ayuda, sin simpatía, sin educación casi, y hoy tenemos otro modo de ser, otras costumbres, otros hijos distintos de los vuestros. Y contad con que sólo queremos ser estados dentro del Estado..." (Payró, 1898, pp. 83-84; grifos nossos)
\end{abstract}

Ainda que admita o caráter idílico dessas passagens, Payró não recua em sua crença inabalável no progresso da Patagônia. Argumenta, a partir do exemplo de Punta Arenas, pela aplicabilidade do modelo anglo-saxão no extremo sul da América:

Australia, California, el Africa del Sur, todo viene al recuerdo cuando se visitan estas regiones recién abiertas al trabajo y la ambición. Punta Arenas (...) 'tiene un clima moralizador', corrige y perfecciona (...). Aquel pueblo, en parte, se compone de piratas, desertores, mineros, loberos, comerciantes sin escrúpulos (...) y sin embargo es un pueblo que (...) puede ser comparado con cualquier otro, y de los más correctos (Payró, 1898, p. 140; grifos nossos).

Num prisma evolucionista, o meio patagônico é apresentado como propício não apenas para o trabalho como também para a regeneração moral ${ }^{25}$ e a forja de self-

\footnotetext{
${ }^{24}$ O Villarino transportava madeira que seria posteriormente usada na construção de linhas de telégrafo na Patagônia. A despeito das grandes dificuldades para estabelecer essas linhas, Payró comenta que sua necessidade era enorme seja para a integração e proteção militar da região (Payró, 1898, p. 314).

${ }^{25} \mathrm{Na}$ mesma linha, o autor estabelece um programa para o melhor aproveitamento do presídio militar de San Juan de Salvamiento, na Isla de los Estados, com vistas à regeneração moral dos presos. Nesse
} 
made $m^{26}{ }^{26}$. Se Payró já vê com bons olhos o povoamento da região por indivíduos desclassificados, tem ainda maior simpatia pelas famílias de pioneers britânicos lá estabelecidas. Os galeses de Santa Cruz, por exemplo, são apontados como exemplos de uma ética capitalista e protestante (Weber, 2017), por sua laboriosidade, resignação às privações materiais e disposição para conquista da natureza. Na retórica adotada pelo autor, a prova dessas supostas virtudes morais seria o desenvolvimento econômico que a região do Chubut teria alcançado nas décadas de 1880 e 1890, a despeito das intervenções e decisões políticas desfavoráveis tomadas pelo governo central ${ }^{27}$.

Outro exemplo é a descrição que o cronista faz de "Mary X", uma jovem inglesa passageira do Villarino, que se dirigia à Patagônia para se casar com um compatriota proprietário rural, há muito radicado no local. "Mary X" é colocada como um protótipo - dada a escolha de um nome genérico para essa personagem - de ditas virtudes morais protestantes, como independência, engenhosidade e ânimo, já que "viene de uno al otro hemisferio, em busca de su pareja, confiada en el varón, fuerte por sí misma" (Payró, 1984, p. 343). Em seguida, ao relatar uma tentativa de flerte que um rapaz portenho faz junto a ela no navio, Payró coloca uma eventual união entre os dois como metáfora do projeto imigratório que sonha para a Patagônia - o povoamento da região por meio da miscigenação entre argentinos e anglo-saxões (Payró, 1984, pp. $343-346)^{28}$.

Para o autor, essa possível união teria claro significado histórico e biológico, na medida em que representaria "la fuerza de atracción de estos países y estas razas nuevas" (Payró, 1984, p. 343). O moço, com sua juventude e brio, é tomado como símbolo de alegadas qualidades e defeitos dos "latinos de América", os quais seriam

programa, Payró defende que o presídio se convertesse em uma colônia penal, na qual os presos gozassem de liberdades para a pesca, a madeireira e a carpintaria (Payró, 1898, p. 418).

${ }^{26}$ Uma das falas de um habitante de Santa Cruz registradas por Payró evidenciam esse ideário: "Aqui he pasado una gran parte de mi vida; todo lo que usted ve, esta estancia, lo he hecho yo con mis proprias manos y es todo mi capital. Si mañana alguno, comprador o arrendatario del gobierno, viene a sacarme de aqui, yo alegaré mi mejor derecho, hasta con las armas si es preciso" (Payró, 1984, p. 320). Em outro momento, Payró comenta que os colonos em Santa Cruz "bastan a si mismos" (Payró, 1898, p. 91).

${ }^{27}$ Por exemplo, a iniciativa do governo central de reduzir a área da colônia agrícola 16 de Octubre, que vinha tendo grande e comprovado êxito, a despeito da pobreza do solo local (Payró, 1898, p. 37)

${ }^{28}$ Esse procedimento de extração de significados gerais a partir do episódico é típico do gênero crônica, que impunha condições de produção diferentes das dos relatos de viagem de militares e cientistas. Requeria uma escrita rápida, em primeira pessoa, possibilitando e exigindo maiores graus de subjetividade, criatividade, concisão narrativa e de fluidez textual (Torre, 2007, p. 153). 
regenerados y reforzados por otras sangres más ingenuas pero más fuertes, viene a ser en el caso, representativo y útil; porque reúne nuestras cualidades de atracción y tiene en su persona y en su modo de ser, la juventud, el desprendimiento, la despreocupación de nuestro país... todo eso malo, que a nadie daña sino a nosotros mismos (Payró, 1984, pp. 343344; itálico do autor; grifos nossos)

Essa caracterização é reveladora da percepção negativa que Payró tem em relação às populações criollas e hispano-americanas. Em um momento em que a intelectualidade modernista discutia a posição das ex-colônias espanholas na América e como esses países deveriam se portar - em termos culturais, econômicos e diplomáticos - perante os ascendentes Estados Unidos, a opção anglófila do jornalista é patente. Tanto é que postula a miscigenação entre argentinos e anglo-saxões - ou escandinavos - como uma suposta forma de "aprimorar" ou "corrigir" racial e culturalmente os primeiros.

Na Patagônia, defende Payró, essa amálgama seria especialmente proveitosa, repetindo o melting pot do Oeste estadunidense. Essa miscigenação suplantaria o antigo lugar ocupado pelas mulheres criollas que haviam acompanhado os exércitos no período da Conquista do Deserto e a antiga mestiçagem entre homens criollos e mulheres indígenas ${ }^{29}$. Para o repórter, nem ameríndias nem hispânicas favoreceriam tanto a criação de núcleos de civilização na Patagônia, pois, diferentemente das imigrantes anglo-saxãs, não estariam bem adaptadas ao clima adverso do meio ${ }^{30}$. Assim, o autor aponta, de maneira determinista, que no extremo austral argentino estaria se formando "una raza distinta de la nuestra" (Payró, 1984, p. 344; grifos nossos).

É interessante notar no trecho acima a maneira com que Payró, por meio da primeira pessoa do plural, se insere dentro de uma identidade hispânica, uma

\footnotetext{
${ }^{29}$ Em La Australia argentina, Payró reconhece o extermínio indígena ocorrido durante a Campanha do Deserto (Payró, 1898, pp. 232-235) e chega a justificar a animosidade dos ameríndios remanescentes como uma forma de vingança contra os colonizadores brancos. Contudo, o autor exclui os indígenas de seu projeto político para a Patagônia, bem como os considera menos evoluídos culturalmente. Dessa forma, o interesse que Payró dedica, em alguns capítulos, aos povos nativos é documental e etnográfico.

${ }^{30}$ Visão análoga é apresentada pelo socialista argentino finissecular José Ingenieros que "concebeu o imigrante como um fator de 'expurgo racial' do elemento mestiço: 'La formación de la nacionalidad argentina $-\mathrm{y}$ de todos los países americanos, primitivamente poblados por razas de color - es en su origen un simple episodio de la lucha de razas; en la historia de la humanidad, podría figurar en el capítulo que estudiará la expansión de la raza blanca, su adaptación a nuevos ambientes naturales y la progresiva preponderancia de su civilización (...). (Ingenieros, 1910, p. 77)"” (Grejo, 2009, p. 75).
} 
identidade associada ao passado. Por outro lado, o jornalista considera a Patagônia, como "espaço de fronteira" destinada a futuramente forjar e abrigar uma "raça" original e nova ${ }^{31}$, pela qual o autor demonstra maior simpatia do que em relação aos "latinos de América". Sintomática dessa percepção do viajante é o fato de atribuir aos argentinos o papel de se adaptarem e se aperfeiçoarem a partir da miscigenação com os imigrantes nórdicos e não que os imigrantes se naturalizassem argentinos e adotassem os hábitos criollos, como queria grande parte das elites intelectuais da época (Grejo, 2009, pp. 75-80).

Em um mundo que presenciava o apogeu do Império Britânico e a vigorosa emergência estadunidense, Payró apostava todas suas fichas em favor dos exemplos políticos e econômicos anglo-saxões. Nessa chave, também fazia apologia às proezas conseguidas nas Ilhas Malvinas. Essas, aliás, foram tomadas pelo autor como exemplo para supor um cenário em que a Inglaterra fosse dona da Patagônia:

Esta sola suposición evoca ideas de actividad, de riqueza, de libertad, de administración, de gobierno proprio, todo un proceso vertiginoso de adelanto... ¿No tenemos ahí, frente á Gallegos, las islas Malvinas? esos escollos cubiertos de turba y sin un árbol, en que vive holgadamente una población ganadera que ya tiene exceso de productos? (Payró, 1898, p. 447)

Na mesma toada, Payró notava que se cumpriu o desejo do navegador quinhentista Gamboa de Sarmiento de desbravamento do extremo austral americano. Não por hispânicos, mas por britânicos. Esses deixaram sua marca em inúmeros nomes na cartografia regional: “Adam (...) Calinford (...) Madryn (...) Wollaston... todos de más ó menos difícil pronunciación para lengua y labios latinos" (Payró, 1898, p. 8).

De qualquer forma, a questão para Payró não é apenas o apreço pelas populações anglo-saxãs em si, mas pelo papel que teriam na criação de uma nova identidade étnica para a Argentina, de maneira a superar a identidade criolla até então dominante. Logo, o autor é um grande defensor da imigração em geral, enaltecendo também a imigração italiana, sobre a qual se deteve no conjunto de reportagens para

\footnotetext{
${ }^{31}$ Essa visão se assemelha à interpretação que Turner faz da formação dos Estados Unidos: "Nossa história inicial é o estudo das raízes europeias que se desenvolvem em meio a um ambiente americano. (...) $\mathrm{Na}$ fronteira, acima de tudo, o ambiente é duro demais para o homem. Ele tem que aceitar as condições que esse meio ambiente lhe oferece, ou perecer (...) pouco a pouco ele transforma a terra remota e inóspita de wilderness, mas o resultado não é a velha Europa (...). O fato é que aqui há um novo produto, que é americano" (Turner, 1994, pp. 25-26).
} 
Los italianos en Argentina (Payró, 1895). Para o jornalista, esse grupo teria trazido grandes benesses econômicas, além de ter proporcionado grandes nomes nas áreas jurídica, militar e política. Também exalta as pretensas virtudes de ordem, esforço e diligência dos italianos. Por conseguinte, as ressalvas de Payró parecem propriamente se dirigir mais contra a Espanha e seu legado colonial na América do que para a Europa latina como um todo.

Vale destacar que Payró e seus companheiros socialistas argentinos partilhavam do otimismo com a massiva leva imigratória europeia que o país então recebia (Devoto, 2000, pp. 54-55) ${ }^{32}$. Sobretudo, pelas possibilidades de mobilização e renovação política que a presença desses novos sujeitos poderia proporcionar, estimulando uma contestação à política criolla hegemônica ${ }^{33}$. Muitos italianos haviam apoiado a Revolução de 1890 e aderido à Unión Cívica (Grejo, op. cit., p. 83).

\section{Patagônia: uma imensa Chivilcoy?}

A apologia de Payró à imigração também pode ser situada em relação ao pensamento político de dois expoentes da Geração de 1837, Alberdi e Sarmiento. O primeiro, em seu Bases y puntos de partida para la organización nacional (1852) afirmava que "governar é povoar", premissa que, como argumenta Fernando Devoto, se desdobrava implicitamente em outra: "povoar é civilizar" (Devoto, 2000, p. 35). Para Alberdi, no que Payró subscreveria, a imigração europeia traria novos comportamentos, que "logo seriam imitados pelos nativos. (...) O papel da imigração seria, portanto, muito mais vasto do que o de fornecer mão-de-obra" (Ibidem, idem). Forjar-se-ia, assim, uma nova identidade nacional argentina ${ }^{34}$, superando a arraigada cultura criolla.

\footnotetext{
${ }^{32}$ O socialista Juan B. Justo, por exemplo, "pensava que o processo imigratório seguiria com a mesma intensidade durante décadas. Isso teria tornado possível uma forma de ação distinta (...), pois continuava existindo um país criollo muito numeroso, que buscava outras formas de expressão" (Di Tella, 2017, p. 195).

33 “ $[L o s]$ nuevos ciudadanos incorporados al país después de la segunda colonización (...) constituyen una democracia nueva que va penetrando y desalojando a las viejas oligarquías residuales de la inmigración colonial." (Ingenieros, 1910 apud Grejo, 2009, p. 76; grifos nossos).

${ }^{34}$ Isso se deveria, para Alberdi, não à transformação racial, mas à transformação cultural que a imigração engendraria (Morse, 1995, p. 77).
} 
Ainda em semelhança com Payró, Alberdi manifestava especial predileção pela imigração norte-europeia, de maneira que em fins de século defendeu a proposição de seleção de imigrantes por parte do Estado argentino, no propósito de privilegiar o perfil anglo-saxão (Ibidem, p. 39), por seus pretenso princípio burguês de valorização do trabalho individual. O seguinte trecho a respeito de Alberdi aplica-se perfeitamente à visão de Payró em relação à concentração da terra na Patagônia e aos alegados méritos dos pioneers anglo-saxões já estabelecidos na região:

\begin{abstract}
Alberdi impugnou essa noção "política", estatista-patrimonialista da propriedade, de acordo com a qual ser rico consistia em ter uma concessão da coroa ou de seus sucessores. Queria substituí-la - tanto em mentalidade social como em direito - por uma concepção lockiana de propriedade como um direito natural, brotando antes do labor individual do que do favor da corte. (Merquior, 2014, p. 154, itálico do autor)
\end{abstract}

As propostas de Payró para a Patagônia também se aproximam do pensamento de Sarmiento. Elegendo como modelo a colônia agrícola de Chivilcoy, na província de Buenos Aires, Sarmiento declarou como parte do programa de sua presidência (18681874) fazer "cem Chivilcoys" para ocupar e eliminar os desiertos argentinos e assim trazer a "civilização" para essas áreas (Ibidem, idem). Tal como Payró, Sarmiento ambicionou "Ilenar un vacío ${ }^{35}$ (...) poblar el desierto americano con las estructuras de la modernidad" (Ramos, 1989, p. 20), embora não tivesse em mente a Patagônia, mas os Pampas, em um cenário pré-Conquista do Deserto. Assim, pode-se dizer que, guardadas as devidas proporções, a Patagônia para Payró seria uma nova e imensa Chivilcoy, proporcionando desenvolvimento econômico e abandonando seu antigo status de desierto.

Também há paralelos entre as ideias de Payró e Sarmiento no que tange à imigração. Em um primeiro momento, na década de 1860, Sarmiento viu os imigrantes prioritariamente como mão-de-obra e não como agentes de transformação cultural. Dessa sorte, diferentemente de Alberdi, não deu tanta prioridade ao perfil nacional do imigrante europeu. Essa percepção, no entanto, se alterou na década de 1880, quando as elites políticas sedimentaram reticências em relação às populações imigrantes já

\footnotetext{
${ }^{35}$ Em carta-prólogo ao livro de Payró (1898, p. v), Bartolomé Mitre também usa a expressão "preencher um vazio", ao se referir à originalidade do livro e ao ver a Patagônia como um território inexplorado.
} 
estabelecidas na Argentina ${ }^{36}$. Sarmiento, assim, procurou delinear uma hierarquia entre os imigrantes de diferentes nacionalidades, alçando os anglo-saxões a um posto de primazia, tal como Payró. Essa avaliação estava lastreada na grande admiração, já manifesta desde Viajes (1849) e Argirópolis (1850), que o autor nutria pelos Estados Unidos. Esse país, em Conflicto y armonía de las razas en América (Sarmiento, 1883), assumiu o status de principal modelo de civilização que deveria ser seguido pela Argentina, segundo Sarmiento - ocupando o posto que fora da França em sua obra anterior $^{37}$.

\section{Anglofilia e evolucionismo no fin-de-siècle: Payró e Francisco}

\section{Bulnes}

A eleição dos Estados Unidos como norte civilizacional por parte de Sarmiento no fin-de-siècle não foi uma opção política isolada. Com a afirmação econômica desse país e a ascensão do evolucionismo no plano ideológico ${ }^{38}$, diversos autores advogavam a superioridade dos povos anglo-saxões a partir de bases teóricas deterministas ${ }^{39}$.

Entre eles, estava o mexicano Francisco Bulnes (1847-1924). Bulnes também rejeitava a formação histórica dos países hispano-americanos e também tomava partido dos anglo-saxões. Em meio à Guerra Hispano-Americana, em posição minoritária na intelectualidade mexicana, Bulnes defendeu a incorporação de Cuba aos

\footnotetext{
${ }^{36}$ Sarmiento, por exemplo, critica fortemente a tendência dos imigrantes a viverem dentro de suas comunidades, desinteressando-se pela língua e pela vida pública nacional (Devoto, 2000, p. 38)

${ }^{37}$ Vale sublinhar, no entanto, as diferenças de concepção entre as apologias que Payró e Sarmiento fazem em relação à imigração anglo-saxã. Enquanto Payró aproxima e nivela as contribuições raciais e culturais dos imigrantes, Sarmiento se concentra mais sobre as segundas. Um exemplo dessa posição de Sarmiento é a comparação que faz entre Estados Unidos e Canadá. $\mathrm{O}$ autor conclui que a existência de uma profunda cultura de associativismo na primeira nação e sua ausência na segunda, se deve a fatores culturais, já que possuem perfil racial muito semelhante (Morse, 1995, p. 85).

38 "En el acto organizado en el Círculo de Médicos de Buenos Aires en 1882 con motivo del fallecimiento de Charles Darwin, Sarmiento pronunció una conferencia en la que mostraba su adhesión a los principios de la teoría de la evolución. En ella dedica (...) diversos elogios al científico y hace un particular repaso del devenir histórico en clave positivista, destacando progresos marcados por los acontecimientos científicos y técnicos" (Pastor; Mora, 2013, p. 691).

${ }^{39}$ Autores, vale destacar, não apenas hispano-americanos, pois os debates e comparações entre latinismo e saxonismo também tinham lugar na Europa na época (Capelato, op. cit., p. 46). Por exemplo, o pedagogo francês Edmond Demolins (1852-1907) publicou em 1897 À quoi tient la supériorité des Anglo-Saxons?, obra na qual - inspirado no historiador inglês Henry Thomas Buckle (1821-1862), pioneiro da análise histórica em bases cientificistas - atribuía os progressos econômicos e imperiais dos anglo-saxões aos seus alegados individualismo e aptidão ao comércio (Rina Simón, 2018).
} 
Estados Unidos (Santos Junior, 2013, p. 152). Bulnes identificava, como muitos outros intelectuais da época, uma "enfermidade" política, econômica e cultural dos países ibero-americanos ${ }^{40}$, tese que desenvolveu na obra El Porvenir de las naciones hispano americanas ante las conquistas recientes de Europa y Estados Unidos (1899) publicada um ano após a viagem de Payró à Patagônia.

Com base nas obras do filósofo evolucionista britânico Herbert Spencer (18201903), Bulnes atribuía esse cenário, de um lado, à origem latina e ao ambiente tropical dessas nações. De outro, às diferenças de concepção e organização política entre países latinos e anglo-saxões. Nos primeiros, os cidadãos estariam submetidos a instituições que seriam alheias a seus interesses como a Igreja, o Exército e o Estado; em contraste, nos segundos, haveria um primado dos indivíduos, de modo que as instituições políticas se curvariam aos interesses do conjunto de cidadãos (Santos Junior, op. cit., p. 86). Dessa forma, entre os anglo-saxões, a pátria seria para os indivíduos, na medida em que

\begin{abstract}
Cada individuo tiene derecho a formar a la patria conforme al ideal de su bienestar individual, limitado por (...) el derecho social (...). Todo este conjunto de riquezas históricas, Morales (...) y materiales que el individuo defiende, es porque en parte es suyo, porque tiene derecho a reformarlo, a aumentarlo (...) Para un anglo-sajón, la patria es el deber, la justicia, la libertad! (Bulnes, 1899, pp. 69-70)
\end{abstract}

Em contraponto, os latinos não se identificariam com suas pátrias, dado que elas não os incorporariam e não representariam uma possibilidade de bem comum ${ }^{41}$ :

Para un latino, la patria ha sido el Estado, la Religión, el Ejército, la Aristocracia, nunca el pueblo ni él! Cada una de esas personas morales ha representado los intereses peculiares de un cierto número de privilegiados (...); la patria de los latinos, hasta ahora, ha sido la voluntad de los que los

${ }^{40}$ Entre tais autores e suas obras, podem ser apontados: Augustín Alvarez (1857-1914), Manual de Patología política (1899); César Zumeta (1860-1955), El Continente enfermo (1899); Manuel Ugarte (1875-1951), Enfermedades sociales (1905); Alcides Arguedas (1879-1946), Pueblo enfermo (1909); e Salvador Mendieta (1879-1958), La Enfermedad de Centro-América (1912).

${ }^{41}$ Nesse sentido, Bulnes, em semelhança a autores como o brasileiro Manoel Bomfim (1868-1932) autor de América Latina: Males de origem (1903) - e o peruano Francisco García Calderón (1883-1953), sustenta a tese do "parasitismo social" como um dos principais problemas políticos da América Hispânica e da Espanha. Na abordagem de Bulnes, o "parasitismo" diria respeito não apenas às elites econômicas e ao Estado, mas a dependência econômica e social de diversos setores sociais em relação a certas instituiçõos - por exemplo, da plebe em relação ao Exército e ao Clero; da classe média em relação aos nobres e ao Estado; da nobreza em relação às riquezas das colônias. O fenômeno do "parasitismo", na América Hispânica, teria sido historicamente forjado a partir do caráter predatório da colonização espanhola, que teria privilegiado a obtenção de riquezas fáceis, estimulando o ócio e o declínio da vida econômica. Em suma, o desprezo ao trabalho, em oposição à América Anglo-Saxã (Bulnes, 1899, p. 103; Santos Junior, 2013, p. 131). 
oprimen; (...) el individuo contra la patria y a favor de los que la aniquilan. (Ibidem, idem; grifo do autor).

Tais ideias assemelham-se significativamente ao diagnóstico de Payró a respeito da Patagônia. Em La Australia argentina, o jornalista insiste no descaso do Estado argentino em relação à região, mostrando-se indiferente às demandas plenamente legítimas, segundo Payró - dos seus habitantes e adotando medidas econômicas contraproducentes. Nessa perspectiva, os patagônicos se sentiam lesados pelo do governo central argentino e impotentes diante dele. Nos termos de Bulnes, nem a "pátria argentina" estaria a favor dos patagônicos, nem esses estariam a favor dela.

Outra semelhança entre Bulnes e Payró é a firme defesa da imigração europeia, prioritariamente a oriunda de zonas extratropicais (Santos Junior, 2013, p. 259). Bulnes também argumentava em favor das pretensas superioridades racial e moral dos europeus em relação aos ibero-americanos ${ }^{42}$, exaltando a produtividade dos primeiros (Ibidem, p. 196). Ademais, Bulnes - assim como Payró e, antes, Alberdi - reconhecia nos imigrantes europeus possíveis vetores "de novos paradigmas políticos (...) baseados em princípios relacionados à pequena propriedade e aos valores liberais" (Ibidem, p. 197). Para Bulnes, isso se daria por meio da substituição da "agricultura aristocrática" que prevalecia desde a colonização por uma "agricultura democrática" e moderna (Ibidem, idem). Eis aí uma semelhança com o repórter do La Nación, que aspirava a um melting pot patagônico como meio para a forja de uma identidade étnica e de um arranjo político que corrigisse os vícios da hegemonia política criolla.

\section{Considerações finais - Um profeta do progresso no desierto}

\section{patagônico}

Logo nos primeiros capítulos de La Australia argentina, Payró decreta:

Diriase que un genio celoso, el mismo que ha trabajado tanto para que no se poblaran aquellas regiones, quiere castigar todavía á los que en ellas ponen el pie, y se entretiene en molestarlos y burlarlos.

\footnotetext{
${ }^{42}$ Bulnes também estende ao caso do Brasil e à colonização portuguesa boa parte de suas análises da América Hispânica e da colonização espanhola (Santos Junior, 2013, p. 197).
} 
Pero (...) ya se ha descorrido el velo que nos ocultaba la Patagonia, y nada podrá detener ahora su rápida población y su progreso continuo (Payró, 1898, p. 20; grifo nosso).

A citação explicita não só um otimismo teleológico em relação ao futuro econômico da Patagônia - como bem notou Andermann (2000, p. 76), o livro se inicia com o título de capitulo "En Marcha" e termina seu último capítulo com a palavra "progreso". O trecho também denota a percepção de que esse potencial existe a despeito de um franco e deliberado desinteresse do governo central argentino pela região, finda a Conquista do Deserto. Para o jornalista, esse seria o maior fator para "barrar o futuro" (Payró, 1898, p. 443) na Patagônia e manter seu aspecto de desierto.

As propostas políticas de Payró para a Patagônia são bastante pormenorizadas, atendendo aos problemas políticos e administrativos das diferentes localidades que visitou. Contudo, seu programa pode ser resumido em duas frentes: a reformulação da política do governo central para a Patagônia e o povoamento da região por meio da imigração europeia - proposição que dialogava tanto com a tradição intelectual argentina da Geração de 1837 como com os autores evolucionistas do fim do século XIX.

Em relação ao primeiro aspecto, Payró defende que as agruras atravessadas pelos patagônicos não adviriam das intempéries climáticas, mas da política de Buenos Aires. Essa não proporcionaria aquilo de que a Patagônia, segundo uma visão quase que liberal, necessitaria: nem a segurança e a infraestrutura pública básica nem liberdades civis, políticas e comerciais para seus habitantes. Payró evoca em seu receituário político os casos do Oeste estadunidense e da Austrália, espaços historicamente pouco explorados nos séculos anteriores, mas que, no século XIX, atingiram considerável desenvolvimento econômico. Tais áreas, sob as lentes do determinismo geográfico, também eram vistas como responsáveis por estimularem o trabalho e, assim, aprimorarem moralmente o ser humano e trazerem prosperidade material. 
Nesse sentido tratar-se-ia de área especialmente recomendada para a imigração ${ }^{43}$. Payró demonstrava especial predileção pelos imigrantes anglo-saxônicos, que seriam os mais indicados para estabelecer na Patagônia uma nova civilização, de princípios burgueses ligados à pequena propriedade e da disciplina do trabalho ${ }^{44}$. Esses imigrantes também permitiriam a forja de um novo perfil étnico na região, oferecendo uma pretensa "evolução" aos argentinos por meio da miscigenação ${ }^{45}$.

Assim, a imigração seria um meio de estabelecer na Patagônia - território tradicionalmente associado, no imaginário portenho, à suposta "barbárie" indígena ou gaucha e ao desierto inóspito - uma civilização de matiz novo e moderno. Civilização essa que redimisse os velhos vícios da política criolla, tão repudiados por Payró.

Quando instado a descrever a Patagônia de maneira concisa, ao gosto do jornalismo moderno, Payró aponta com entusiasmo a região como "Una nueva América!" (Payró, 1898, p. 111). O adjetivo "nova" pode remeter, dada a posição anglófila do autor, aos recentes avanços econômicos e geopolíticos que os Estados Unidos vinham galgando, uma vez que La Australia argentina foi escrita em meio à vitória norte-americana na Guerra Hispano-Americana. Em contraponto, a América Hispânica, herdeira de um Império em plena decadência, pode ser implicitamente identificada como "velha" na obra. Para "rejuvenescer" e modernizar a Argentina, o caminho proposto seria o de criar um Oeste estadunidense no Far South patagônico.

A anglofilia de Payró não era hegemônica nos círculos intelectuais portenhos da época. Diferentemente de seu amigo e contemporâneo Rubén Darío, que considerava a ascensão dos Estados Unidos como “o triunfo de Calibán” (Darío, 1998), Payró não é refratário à cultura "pouco idealista" estadunidense (Ibidem, p. 451). O autor considera essa cultura mais "pragmática" como um elemento benéfico, que propiciaria modernização econômica, prosperidade material e aperfeiçoamento moral. Esses atributos, que o repórter, em uma lógica turneriana, reputa aos espaços de fronteira

\footnotetext{
${ }^{43}$ Payró considerava especialmente necessária a bandeira pelo povoamento da Patagônia por meio da imigração, uma vez que os afluxos imigratórios para a Argentina ainda estavam muito concentrados nas grandes cidades, sobretudo, na "cabeça" do país, Buenos Aires (Payró, 1898, p. 444).

${ }^{44}$ A valorização do binômio imigração e laboriosidade por parte de Payró é explicitada quando conclama às "portas" da Patagônia se abrirem aos trabalhadores de todo mundo (Payró, 1898, p. 448). Nesse apelo, podem-se ouvir ecos de certo materialismo e internacionalismo socialistas, ainda que em perspectiva não revolucionária.

${ }^{45}$ Payró (1895; 1898, p. 443) descartava os riscos de avanços imperiais sobre a Argentina (Devoto, op. cit., p. 41), a partir da justificativa de esse país abrigar colônias italianas ou britânicas.
} 
como a Patagônia, teriam inclusive um potencial democratizante ${ }^{46}$, pelo qual o jornalista demonstra simpatia. Vale ressaltar que o regime político democrático estadunidense seria criticado, poucos anos depois, por José Enrique Rodó (1993) em Ariel (1900), obra que defendia o protagonismo de uma "aristocracia espiritualista" na vida social da América Hispânica.

Por fim, cabe ressaltar a dimensão ensaística do relato de Payró. Ao tomar partido anti-criollo e anti-hispânico, ao explicar a realidade social da Patagônia e ao pregar o desenvolvimento econômico da região, o autor combina três das principais representações do intelectual no ensaio hispano-americano oitocentista, segundo Beatriz Colombi (2007, pp. 25-36). São elas: a do "polemista", que escreve contra determinada instituição ou fenômeno político; a do "maestro", que detém e transmite um conhecimento especializado; e a do "profeta", que antevê um futuro político.

No livro, as facetas de "maestro" e "polemista" estão intimamente articuladas com a de "profeta" e a serviço desta. Destrinchando para os leitores portenhos os problemas patagônicos, bem como rechaçando as medidas do governo central, Payró busca dar peso argumentativo ${ }^{47}$ a um eufórico vislumbre de futuro alternativo para a área. Em sua utopia patagônica, a imigração e a integração territorial acelerariam o progresso econômico na região e permitiriam a formação de uma sociedade, uma política e uma identidade racial supostamente mais aptas para a modernidade.

\section{Fontes}

PAYRÓ, R. J. 1895. Los italianos em Argentina. Buenos Aires: Imprenta La Nación.

1898. La Australia argentina: excursión periodística a las costas patagonicas, Tierra del Fuego e Isla de los Estados; con una carta-prólogo de Bartolomé Mitre. Buenos Aires: Imprenta La Nación, dos tomos [Disponível on-line em: < http://trapalanda.bn.gov.ar/jspui/handle/123456789/2899 >. Acesso em 24-11-2017.].

\footnotetext{
${ }^{46}$ Esse potencial seria visto na capacidade que o espaço teria para regenerar moralmente aventureiros e ex-criminosos. Oferecendo-lhes amplas liberdades, eles poderiam se tornar prósperos self-made men.

${ }^{47}$ De acordo com Sarlo (1984), a produção literária e jornalística de Payró era marcada por um acentuado tom didático, a serviço da argumentação em prol de determinadas teses políticas. Esse caráter utilitário aparece nas últimas páginas de La Australia argentina. Nelas, o autor comenta que espera que seu livro, mais do que literariamente reconhecido, seja útil para que "el Gobierno y los hombres de empresa fijen su atención en las regiones que recorri, el uno para incorporarlas definitivamente á la existencia nacional, los otros para llevar a elllas sus iniciativas y sus esfuerzos (...)” (Payró, 1898, p. 443).
} 
1984. La Australia argentina: excursión periodística a las costas patagonicas, Tierra del Fuego e Isla de los Estados. In: . Obras. Caracas: Biblioteca Ayacucho.

2012. Divertidas Aventuras del Nieto de Juan Moreira. 1a ed. 1910. Buenos Aires: Editorial Eudeba.

\section{Referências bibliográficas}

ANDERMANN, J. 2000. "Reporters en la frontera Periodismo de viaje e imaginación progresista en Payró y Arlt". Buenos Aires, El Rodaballo, año 6, no 10, pp. 72-77.

BARRERA, N. 2011. "El evolucionismo en el pensamiento socialista argentino: la obra de Juan B. Justo y Alfredo Palácios". KAIROS Revista de Temas Sociales, ISSN 1514-9331, Publicación de la Universidad Nacional de San Luís, año 15, no 28.

BULNES, F. 1899. El Porvenir de las naciones hispano americanas ante las conquistas recientes de Europa y Estados Unidos. México: Imprenta de Mariano Nava.

BUONUOME, J. 2017. "Los socialistas argentinos ante la 'prensa burguesa'. El semanario La Vanguardia y la modernización periodística en la Buenos Aires de entresiglos". Boletín del Instituto de Historia Argentina y Americana "Dr. Emilio Ravignani", Tercera serie, núm. 46, pp. 147-179.

CAPELATO, M. H. R. 2003. "A data símbolo de 1898: o impacto da independência de Cuba na Espanha e Hispanoamérica". História, São Paulo, 22 (2): 35-58.

COLOMBI, B. 2004. Viaje intelectual: migraciones y desplazamientos en América Latina, 18801915. Rosário: Beatriz Viterbo editoria.

. 2007. "Representaciones del ensayista". The Colorado Review of Hispanic Studies, vol. 5, pp. 25-26.

DARíO, R. 1998. “El triunfo de Calibán". 1a ed. 1898. In: Revista Iberoamericana, v. 64, n. 184185.

DEVOTO, F. J. 2000. "Imigração europeia e identidade nacional nas imagens das elites argentinas (1850-1914)". In: FAUSTO, Boris (org.). Fazer a América. A imigração em massa para a América Latina. 2a edição. São Paulo: Edusp.

DI TELLA, T. 2017. História social da Argentina contemporânea. 2ª ed. rev. Brasília: FUNAG.

GREJO, C. B. 2009. Carlos Octavio Bunge e José Ingenieros: entre o científico e o político Pensamento racial e identidade nacional na Argentina (1880-1920) [online]. São Paulo: Editora UNESP; São Paulo: Cultura Acadêmica. 131 p. ISBN 978-85-98605-98-2. Disponível em: SciELO Books. 
GROUSSAC, P. 1898. "Discurso del sr. Groussac". In: España y Estados Unidos. Buenos Aires: Compañia Sud-Americana de Billetes de Banco.

HALPERÍN DONGHI, T. 2005. Una nación para el desierto aregentino. Buenos Aires: Prometeo Libros.

HARTOG, F. 1999. O espelho de Heródoto: ensaio sobre a representação do outro. Belo Horizonte: Editora da UFMG.

HOBSBAWM, E. 2011. A era dos Impérios, 1875-1914. Rio de Janeiro: Paz e Terra.

INGENIEROS, J. 1910. La evolución sociológica argentina: de la barbarie al imperialismo. Buenos Aires: Librería J. Menéndez.

INOSTROZA PINO, L. 2008. "La evolución del espacio social y urbano en la capital de la patagonia chilena". Punta Arenas, Urbano (Universidad del Bío Bío Concepción, Chile), vol. 11, núm. 17, mayo, pp. 15-25

MERQUIOR, J. G. 2014. O Liberalismo - antigo e moderno. 3a ed. São Paulo: É Realizações.

MIGNOLO, W. 2012. "'Latin' America and the first reordering of the Modern/Colonial World". In: The idea of Latin America. Malden: Blackwell Publishing.

MORSE, R. 1995. O espelho de Próspero. Trad. Paulo Neves. São Paulo: Companhia das Letras.

MONTALDO, G. 2013. "Prólogo". In: DARÍO, Rubén. Seleção e Prólogo de Graciela Montaldo. Viajes de um cosmopolita extremo. Buenos Aires: Fondo de Cultura Econômica, pp. 11-51.

PARSON, G. 2001. "El nacimiento del movimento obrero em Argentina entre aguas turbulentas: reformistas y revolucionários". In: CAMPINS, Mónica (org.). Conservadores, progressistas y revolucionarios en los siglos XIX y XX. Buenos Aires: Ediciones del signo, pp. 5569

PASSETTI, G. 2012. Indígenas e criollos: política, guerra e traição nas lutas no sul da Argentina (1852-1885). 1. ed. São Paulo: Alameda.

2014. "O Estreito de Magalhães redescoberto: CIÊNCIA, POLÍTICA E COMÉRCIO NAS EXPEDIÇÕES DE EXPLORAÇÃO NAS DÉCADAS DE 1820 E 1830". Londrina, Antíteses (Universidade Estadual de Londrina), v. 7, n. 13, p. 254-276.

PASTOR, J. M. A. e MORA, V. G. 2013. "El imaginario tecnológico de Domingo Faustino Sarmiento: representaciones y arquetipos de América (1845-1885)". Anuario de Estudios Americanos, 70, 2 Sevilla (España), julio-diciembre, 673-697 ISSN: 0210-5810. DOI: 10.3989/aeamer.2013.2.10

PASTORMELO, S. 2009. Payró en Pago Chico 1887-1892: Periodismo, revolución y literatura. 1a ed. - La Plata: Universidad Nacional de La Plata.

PERA, C. 1998. "De viajeros y turistas: reflexiones sobre el turismo en la literatura hispanoamericana". Revista Iberoamericana. Vol. LXIV, Nuims. 184-185, p. 507-528. 
POMPEU, A. C. G. 2012. A construção da Patagônia argentina. Dissertação de Mestrado. Universidade Nacional de Brasília, Programa de Pós-graduação em História - PPGHIS. Brasília.

RAMOS, J. 1989. Desencuentros de la modernidad en América Latina: Literatura y política en el siglo XIX. México D.F.: FCEM.

RINA SIMON, C. 2018. "Proyección exterior, hispanoamericanismo y regeneración nacional en la península Ibérica en el siglo XIX". Hist. mex., Ciudad de México , v. 67, n. 4, p. 1597-1631. Disponible en <http://www.scielo.org.mx/scielo.php?script=sci_arttext\&pid=S244865312018000201597\&lng=es\&nrm=iso>. accedido en 11 jul. 2018. http://dx.doi.org/10.24201/hm.v67i4.3565.

RODÓ, J. E. 1993. Ariel y Motivos de Prometeo. "Ariel”. Caracas: Biblioteca Ayacucho.

ROJAS, G. 2013. "Os partidos políticos de matriz socialista do marxismo na Argentina (18942006)". Anais do V Simpósio Internacional Lutas Sociais na América Latina "Revoluções nas Américas: passado, presente e futuro" - GT 8. Marxismos latino-americanos. ISSN 2177-9503, pp. 70-102.

SARMIENTO, D. F. 1997. Facundo: civilização e barbárie. Tradução de Jaime A. Clasen. 1ạ ed. 1845. Petrópolis: Editora Vozes.

1849. Viajes por Europa, África y América. Santiago de Chile: Imprenta de Julio Belin y cia.

1913. Argyropolis. 1a ed. 1850 OC, T. XIII. Buenos Aires: Librería La Facultad, de Juan Roldán.

1883. Conflicto y armonías de las razas en América. Buenos Aires.

SANTOS JUNIOR, V. D. dos. 2013. "A trama das ideias: intelectuais, ensaios e construção de identidades na América Latina (1898-1914)". Dissertação (Mestrado) - Faculdade de Filosofia, Letras e Ciências Humanas, Universidade de São Paulo, São Paulo.

SARLO, B. 1984. “Prólogo”. In: PAYRÓ, R. J. Obras. Caracas: Biblioteca Ayacucho.

SCHWARZ, R. 2012. Um mestre na periferia do capitalismo: Machado de Assis. 5ạ edição. São Paulo: Editora 34.

TORRE, C. I. 2007. "Literatura em tránsito. La narrativa expedicionaria de la Conquista del Desierto (Argentina 1870-1900)". Tesis presentada con el fin de cumplimentar con los requisitos finales para la obtención del título Doctor en Letras. Buenos Aires: Facultad de Filosofía y Letras, Universidad de Buenos Aires.

TORRE, C. I. 2010. Literatura en tránsito. La narrativa expedicionaria de la conquista del desierto. Buenos Aires: Prometeo Libros.

TURNER, F. J. 1994. "The Significance of the Frontier in American History". In: FARAGHER, John Mack (ed.). Rereading Frederick Jackson Turner "The Significance of the Frontier in American History" and Other Essays. New York: Henry Holt, pp. 31-60. 
2004. "O Significado da fronteira na História americana". In: KNAUSS, P. Oeste Americano. Niterói: Ed.UFF.

WEBER, M. 2017. A ética protestante e o espírito do capitalismo. 1a ed. 1905. São Paulo: Companhia das Letras.

Tramitação do artigo na revista Submetido: 16/08/2018

Revisões requeridas: 07/03/2019

Versão revista: $21 / 03 / 2019$

Aceito: 21/03/2019 